\title{
Reproductive Snakehead Fish (Channa striata Bloch, 1793) in Swamps Waters
}

\author{
Sunarni Sunarni*, Sisca Elviana, and Stenly M B S Wairara \\ Department of Aquatic Resources Management, Faculty of Agriculture, Universitas Musamus, Merauke 99600, Indonesia
}

\begin{abstract}
The purpose of this study was to determine the reproduction of Snakehead fish (Channa striata Bloch, 1793) in the waters of the Merauke district wasur swamp. The data analysis used was the sex ratio, the level of gonad maturity, and the first size of gonad maturity. The results showed that the sex ratio of male and female snakehead fish in October and November at stations I and II tended to be balanced, while in September the sex ratio of snakehead fish at station I was balanced and at station II was not balanced. The maturity level of snakehead fish gonads at TKG III in September was around 35.48\%, in October $28.57 \%$ and $15.38 \%$ in November. The size of the first time the gonads were ripe, the results showed that the first time the fish were ripe, the gonads were $190 \mathrm{~mm}$ long and weighing $50.3 \mathrm{~g}$.
\end{abstract}

Keywords: Reproductive, Snakehead fish, Wasur swamp

\section{Introduction}

Sneakehead fish is a type of fish that lives in the freshwater swamp waters of the Wasur village. By the local community, Snakehead fish is used both in fresh condition and in other processed forms. Some of these types of preparations include salted fish, shredded meat, meatballs and so on, triggering high market demand for Sneakehead fish. In 2003 Makmur et al. [1], Explained that in the Sumatra region the form of snakehead fish processing is the raw material for the manufacture of crackers and pempek, which are processed products typical of the Sumatra region. In Merauke district, this type of fish is very popular for consumption as a source of animal protein, so it has a high economic value. Catching and exploiting Snakehead fish without conservation will gradually affect the survival of the fish.

One form of conservation efforts for the presence of Snakehead fish in its natural habitat is by identifying reproductive biology [1]. Explained that fish reproductive biology is a fundamental aspect of fish biology which is very important for the management and utilization of fishery resources. Study of sex and maturity level of gonads (TKG) constitutes basic knowledge of the reproductive biology of a preparation and its reproductive potential. Development TKG can be related to the size of the fish, namely the length when the gonads first ripen. As for research related to the biology of Snakehead fish reproduction such as sex ratio, and size of the first maturity of Snakehead fish gonads in Wasur swamp waters have not been widely studied. Therefore, the aim of this study is to analyze the reproductive biology of Snakehead fish caught in the Wasur swamp waters of Merauke Regency, which includes the sex ratio, TKG and the size of the first maturity of the gonads. This information can be used as a basis for fishing arrangements in the Rawa Wasur area. In addition, this information can also be used as a basis for habitat management in determining conservation areas (fisheries reserves).

\section{Methodology}

\subsection{Time and Place}

This research was conducted from September to November 2020 in the waters of the Wasur swamp, Merauke district. Sampling was carried out at two stations, namely station I located at the coordinate point S $8^{0} 31^{\prime} 21,59^{\prime \prime}$ and E $140^{\circ} 30^{\prime} 58,55^{\prime \prime}$ and station II is located at the coordinate point S $8^{0} 30^{\prime} 46,89^{\prime}$ ' and E $140^{\circ}$ 30 ' 14,67 .

\subsection{Tools and Material}

The tools and materials used in this research are GPS, coolbox, tray, cutter knife, surgical board, a set of surgical tools, pins, 1-inch tensile nets, analytical scales, rulers, gloves, tissues, masks.

\footnotetext{
* Corresponding author : sunarni@unmus.ac.id
} 


\subsection{Sampel}

The sample used in this study was the Snakehead fish (Channa striata Bloch, 1793) were captured at both stations during the study.

\subsection{Method}

The method used in this research is descriptive method and the sampling technique is purposive sampling. Sampling using 1 inc nets and carried out once/month for three consecutive months.

\subsection{Data Analysis}

Data were analyzed using the sex ratio equation according to [2] to determine the sex ratio. TKG uses the equation according to [3]. The size of the first maturity of the gonads was analyzed using the Spearmen-Karber method [4].

\section{Results and Discussion}

Based on the results of the study, the number of fish caught during the study amounted to 204. Comparison of sex ratios at each station based on month shows a different pattern. This data is shown in Table 1.

Table 1. Sex Ratio of Sneakehead Fish based on the month of observation

\begin{tabular}{|c|c|c|c|l|}
\hline \multirow{2}{*}{ Month } & Station & $\begin{array}{c}\text { Sex } \\
\text { ratio }\end{array}$ & $\begin{array}{c}\text { Count } \\
\mathbf{X 2}\end{array}$ & Information \\
\hline \multirow{2}{*}{ September } & I & $1.6: 1$ & 1.77 & Balanced \\
\cline { 2 - 5 } & II & $0.4: 1$ & 8.39 & Not Balanced \\
\hline \multirow{2}{*}{ October } & I & $0.7: 1$ & 1.6 & Balanced \\
\cline { 2 - 5 } & II & $0.5: 1$ & 3.12 & Balanced \\
\hline \multirow{2}{*}{ November } & I & $0.6: 1$ & 1.96 & Balanced \\
\cline { 2 - 5 } & II & $1.2: 1$ & 0.14 & Balanced \\
\hline
\end{tabular}

Based on the analysis, the sex ratio of Snakehead fish in October and November at the two stations tends to be balanced or not significantly different. In September, the sex ratio of Snakehead fish at station I was balanced and station II was not balanced. [5], states that if the sex ratio of male and female fish is balanced, it shows that the population condition is still ideal in maintaining its sustainability. The results of the TKG analysis of male fish found during the study were TKG I and II, while the female TKG found were TKG I, II and III. TKG of male fish at station I had a percentage of $100 \%$ immature gonads because they were still at TKG I, while at station II TKG II was found in October. The percentage of male snakehead fish TKG each month is shown in Figure 1.

Based on the results of the research conducted, 119 female Snakehead fish were found with TKG ranging from TKG I to III (Figure 1). At station I, the percentage of TKG I in September, October and November were
$57.14 \%, \quad 58.33 \%$ and $68.75 \%$, respectively. The percentage of TKG II in September, October and November were $14.28 \%, 25 \%$ and $12.5 \%$, respectively. Snakehead fish are said to be mature when the gonads reach TKG III and IV.

\section{TKG Snakehead Fish Male Station 1}

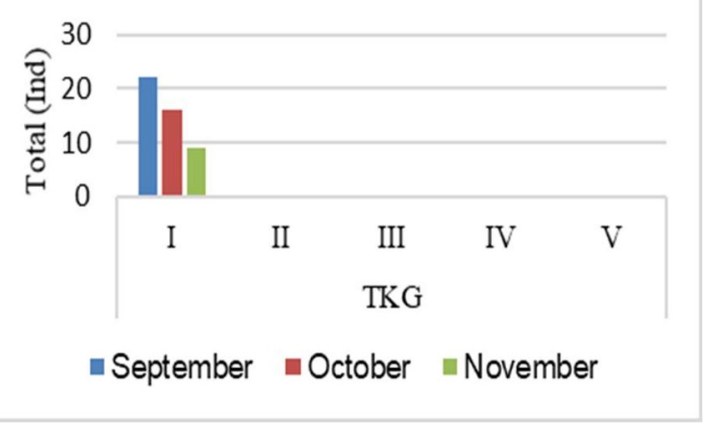

\section{TKG Snakehead Fish Male Station 2}

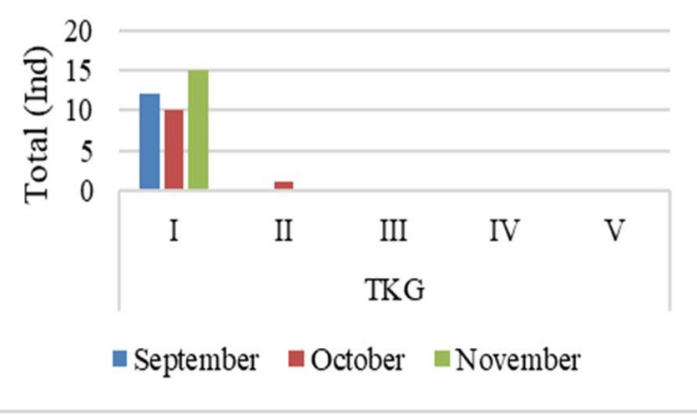

Fig. 1. TKG Snakehead fish male

The percentage of Snakehead fish that had matured gonad in September, October and November were $28.57 \%, 16.67 \%$ and $18.75 \%$, respectively. Based on the percentage, it can be concluded that the peak of Snakehead fish spawning at station I occurred in September. This is in line with research conducted by [1], that the peak spawning of snakehead fish usually occurs from September to December.

At station II, the percentage of TKG I in September, October and November were $32.26 \%, 33.33 \%$ and $61.54 \%$, respectively. The percentage of TKG II in September, October and November were $32.26 \%$, $38.09 \%$ and $23.08 \%$, respectively. The percentage of TKG III (snakehead fish that have matured gonads and are ready to spawn) in September, October and November were $35.48 \%, 28.57 \%$ and $15.38 \%$, respectively. Based on the percentage, it shows that Snakehead fish at station II experienced a peak of spawning in September. The size of the first time gonads ripen based on the results of the research carried out is that they have a body length of $190 \mathrm{~mm}$ and a weight of $50.3 \mathrm{~g}$ while the largest size of fish has a body length of $450 \mathrm{~mm}$ and a weight of $900 \mathrm{~g}$. The size at first maturity of gonads in fish varies, this is influenced by several factors such as food availability, fish life strategies, adaptation patterns and fish growth rate. [6] explained that the size of snakehead fish caught in the Tambat 
swamp had small TKG with a weight of $343 \mathrm{~g}$ and a total length of $342 \mathrm{~mm}$. The largest sizes reach $2300 \mathrm{~g}$ in weight and $60.7 \mathrm{~mm}$ in length. Another case with research conducted by [1] explained that the size of the first mature snakehead fish gonaad ranged from $180 \mathrm{~mm}$ and males $154 \mathrm{~mm}$.

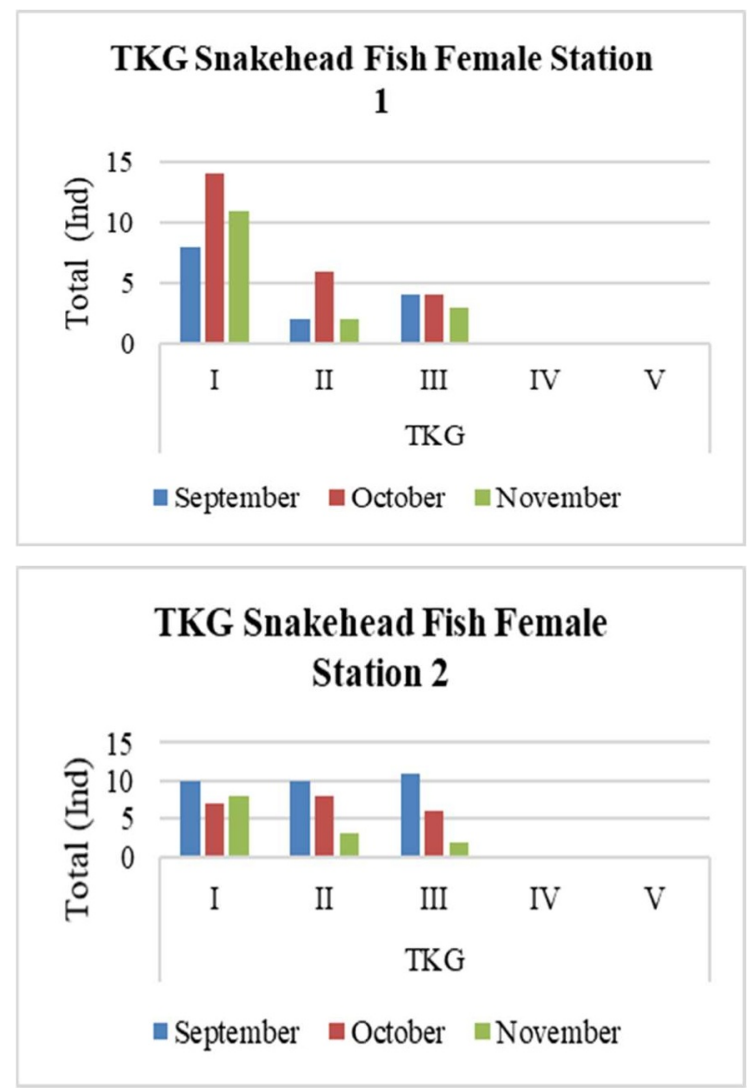

Fig. 2. TKG Snakehead fish female

\section{Conclusion}

Based on the results of the research conducted, the TKG of male and female Gabus in the two stations in October and November tended to be balanced, while in September the TKG in Sembang Station I and Station II were not balanced. TKG III of snakehead fish in September, October and November were $35.48 \%$, $28.57 \%$ and $15.38 \%$, respectively. The size of the firsttime gonads ripen are $190 \mathrm{~mm}$ long and weigh $50.3 \mathrm{~g}$.

The author thanks Musamus University for funding research activities through the Unmus internal superior research for the 2020 fiscal year number; $179.4 / \mathrm{UN} 52.8$ / $\mathrm{LT} / 2020$

\section{References}

1. Makmur S Rahardjo MF Sukimin S, "Biologi Reproduksi ikan gabus (Channa striata Bloch) di Daerah Banjiran Sungai Musi Sumatera Selatan," Iktiologi Indones., vol. 3, no. 2, pp. 57-62, (2003).
2. Steel RGD and JH Torrie, "Principles and procedures of statistic," in Graw-Hall, 2nd ed., New York: Book Comp, (1980).

3. Effendie MI, "Penilaian Perkembangan Gonad Ikan Belanak. Liza subviridis va- lenciennes, Diperairan Muara Sungai Cimanuk. Indramayu, bagi usaha pengadaan benih," Institut Pertanian Bogor, (1984).

4. Udupa KS, "Statistical method of estimating the size at first maturity in fishes," Fishbyte, vol. 4, no. 2, pp. 8-10, (1986).

5. Saputra SW Soedarsono P Sulistyawati GA, "Beberapa Aspek Biologi Ikan Kuniran (Upeneus spp) di Perairan Demak Semarang," J. Saintek Perikanan. UNDIP, vol. 5, no. 1, pp. 1-6, (2009).

6. Andi Wakiah Achmar Mallawa Faisal Amir, "Struktur Ukuran dan Ukuran Pertama Kali Matang Gonad Ikan Gabus (Channa striata) di Danau Tempe Kabupaten Wajo," Pros. Simp. Nas. Kelaut. dan Perikan. VI, vol. IV, (2019). 